\title{
АКАДЕМИЧЕСКОЕ ПИСЬМО
}

DOI: https://doi.org/10.31992/0869-3617-2020-29-5-64-72

\section{Integrative Teaching Strategy for Developing Writing Skills in Non-Linguistics Master Students}

\author{
Elena A. Komochkina - Cand. Sci. (Education), Senior Lecturer, e-mail: \\ Komochkina2010@yandex.ru \\ National Research Nuclear University MEPhI, Moscow, Russia \\ Address: 31, Kashirskoe shosse, Moscow, 115409, Russian Federation \\ Moscow Region State University, Moscow, Russia \\ Address: 24, Very Voloshinoy str., Mytishchi, Moscow region, 141014, Russian Federation \\ Ludmila V. Yarotskaya - Dr. Sci. (Education), Prof., e-mail:1vyar@yandex.ru \\ Moscow State Linguistic University, Moscow, Russia \\ Address: 31, Ostozhenka str., Moscow, 119034, Russian Federation
}

\begin{abstract}
The paper discusses some interdisciplinary, contextual, and linguistic aspects of developing language skills essential to writing scientific papers. The suggested strategy provides a theoretical foundation for designing an integrated teaching strategy that incorporates three basic components: teaching writing skills and subskills in a foreign language, using an online teaching platform, and the universality of the scientific language that underlies scientists' professional communication all over the world. The paper identifies gaps in teaching writing skills in a foreign language, reveals typical mistakes, and proposes a way of their overcoming through introducing the integrative teaching strategy into the education process. The paper also focuses on some ways of implementing the strategy relative to the integration of traditional and online teaching of master students through their investigating specialist discourse elements, identifying formulaic expressions and grammar patterns with a view to using them in their profession-related discourse, learning to rely on those findings in producing a coherent text, and thus, developing their capacity to write clearly and effectively.
\end{abstract}

Keywords: Scientific English course, foreign language, non-linguistics universities, scientific discourse, integrative teaching strategy, writing skills

Cite as: Komochkina, E.A., Yarotskaya, L.V. (2020). Integrative Teaching Strategy for Developing Writing Skills in Non-Linguistics Master Students. Vysshee obrazovanie v Rossii = Higher Education in Russia. Vol. 29, no. 5, pp. 64-72.

DOI: https://doi.org/10.31992/0869-3617-2020-29-5-64-72

\section{Introduction}

Teaching writing skills and subskills to master students for the purposes of future professional communication within the international scientific community is one of the most promising and challenging research areas in Russian non-linguistics universities. Literature review has shown that developing professional wri- ting skills refers to one of the areas widely discussed by LSP (language for specific purposes) foreign [1-4], and Russian researchers [5-12] who stress the importance of interdisciplinary and contextual approach in teaching a foreign language.

Conventionally, most LSP teaching courses are based on: 
- power writing approach including a formula for writing paragraphs and helping learners to identify the main idea and provide it with supporting sentences [13];

- product-oriented approach focused on imitating and transforming model texts [14];

- free-writing approach allowing students to express their thoughts freely and thus, contributing to their creativity and self-discovery [14];

- grammar-syntax-organization (GSO) approach linking the purpose of a piece of writing to the forms necessary to convey the message [14];

- genre-based approach aimed at studying the text topology, which involves some specific mechanisms and practices of communication within the professional community $[6 ; 11 ; 15]$;

- deep-end classroom methodology based on text analyzing, problem solving and discussing both model and real situations [2].

Evidently, each of the approaches proves quite productive in serving individual goals for teaching writing as classroom activity, but teaching writing skills and subskills also needs an integrated teaching strategy incorporating the most effective components of those approaches and showing good potential for further innovation and technological "tuning" to meet the growing educational needs and demands of society. In this respect, an important trend to consider is the use of distance and mobile technologies within the integrated approach to preparing a new generation of professionals. Its underlying idea is that present-day language pedagogy instruments should incorporate instant professional context modelling paired with the use of traditional resources [16].

The integrative teaching strategy in question was designed to embrace all those possibilities and further develop them. Research into distance and mobile teaching and learning as a significant avenue of enquiry in language pedagogy was consolidated with the recent studies of writing as a type of speech activity in professionrelated communication. The paper identifies gaps in teaching writing skills in a foreign language, along with research questions, methodology, and suggests introducing the integrative teaching strategy into the education process for teaching written professional communication by giving a description of the method, some theoretical foundation, expedience of its use, as well as its stages and language components to be studied.

Comparative analysis of written texts linguistic features has been made by a lot of researchers [10; 17-20]. However, the developed course of scientific English is specially designed to teach writing skills to non-linguistics students.

\section{Theoretical Foundation}

Teaching present-day students of a non-linguistics university to communicate professionally (orally or in writing) in a foreign language needs new methodology based on thorough analysis of a wide range of factors. The methodological underpinning of the research that the article covers embraces Vygotsky's cultural-historical theory, which emphasizes the role of collective activity in the development of an individual [20], the ideas of competency-based learner-centered teaching implemented in productive education theory [22] and the higher education language pedagogy principle of internationalization of non-linguists' vocational training [11].

That demanded changes in the educational model, revision of methods used and adequate selection of the content of teaching professionrelated foreign language writing.

As a result of these changes, master students are expected to acquire comprehensive skills in:

- developing complex ideas concerned with areas of scientific interest;

- using, creating, and interpreting visuals from data, experiments, and research as well as describing mathematical symbols (equations, numeral expressions, diagrams, etc.);

- recognizing and using inference and implications in subject-oriented texts;

- working out research hypotheses and a research subject;

- analyzing, classifying, summarizing, correlating obtained scientific results;

- describing an experiment or an experimental set-up; 
- identifying a research purpose/problem;

- using language signposts to highlight main ideas and details of an experimental setup;

- presenting a task and characterizing the methods of solving it;

- demonstrating and evaluating received results;

- identifying, outlining and describing processes in research, lab works and experiments;

- explaining theoretical and practical value of received results;

- comparing values, diagrams, equations, solutions, conditions, results, etc;

- using generalizations to frame an introduction, definition, or summary;

- distinguishing facts and opinions and hedging when presenting or writing scientific research;

- studying some other common text features (references, use of abbreviations, italics, brackets);

- summarizing key ideas.

The underlying teaching technique suggests that non-linguistics master students learn formulaic expressions while performing tasks aimed at writing a conference report, review paper, research report, structured or unstructured abstract, introduction/conclusion to a research paper, presenting some background information or a short summary.

Universal speech patterns to be mastered are lexical and grammar structures of the language used to perform specific functions in modern scientific discourse, such as paraphrasing key ideas, clarifying statements, identifying and presenting main ideas and supporting details, developing an idea, describing visuals, making assumptions, determining a degree of certainty, using generalizations and specific information, presenting wellintegrated research, distinguishing between facts and opinions in texts, synthesizing information from multiple sources, selecting suitable research to support the developed ideas, identifying facts through verbal and non-verbal signposts, synthesizing text into a visual, evaluating the results, describing research methods, proposing new solutions to the problem, etc.
The suggested approach is aimed both at motivating students for simultaneous learning of some universal speech patterns in a foreign language and at teaching them to correctly use the selected material in their professional area. It is essential to note that this educational goal should be achieved within a very limited time period (one semester).

Therefore, scientific discourse elements of a foreign language should become an integral part of bachelor and master course curricula in a non-linguistics university. Besides, since it is English that is the language of international and intercultural scientific communication, we should try to provide students with English formulaic phrases while developing language skills and subskills related to scientific writing.

In addition, the role of mathematics as the universal language of professional communication among scientists needs emphasizing in teaching profession-related writing, which results from the fact that a great deal of information is delivered by the scientific community through the unified system of meaningful symbols. Mathematical formulae, charts, graphs, equations, tables which characterize scientific discourse can provide a link between concepts available in the student's native language and the target language. According to A. Remache, "the learning of science entails the acquisition of knowledge of certain universal concepts which are peculiar to scientific and technological texts. Widdowson advocates the theory that the basic concepts of science are universal, irrespective of the native language of the scientists. That means to say that these scientific concepts make up cognitive deep structures which can be realized in various languages throughout the world as "a textualization of a variety of discourse... which scientists and technologists acquire through education" [20].

\section{Language Problems and Ways of their Overcoming}

Foreign language teachers in a non-linguistics university are encountered with the problem of a low general linguistic level of their stu- 
dents and their low motivation for developing foreign language skills acquired at school or at a bachelor's program. Besides, the university curriculum does not afford enough hours for forming and developing students' skills in professional communication, which, within a workplace context, encompasses written, oral, visual, and digital forms of presentation. The discipline has to combine technology, software, and learning theory in how to improve and deliver communication in a variety of activities. It also focuses on the study of information obtained from authentic sources and the ways it is created, managed, distributed, and, obviously, expressed in a foreign language. Taking into account all those factors, we have developed a course based on present-day textbooks "Insight into the Structure. Textbook for Physics Master Students" [23] and "University Success Oral Communication, Transition Level with MyEnglishLab" [24] designed for solving some of the problems encountered by teachers of foreign language.

The program encompasses:

- systematic skill development assisting students in using English language features, in comprehending, in synthesizing new information; easy recognition and use of stable word combinations, fixed phrases, and word-building elements;

- basic grammar notions, specific for professional written communication;

- strategies for academic success delivered via online lectures, context-based vocabulary;

- continuous formative assessment offering different points of feedback, in class and online through listening to lectures on subject-oriented topics;

- research-based teaching meant to use student projects through collaborative work between teachers of various departments [25].

The ultimate goal of the course is to provide students with a measurable skill that can increase their qualifications for future scientific activities. In other words, it is meant to help the student make a better use of his/her job experience through learning the language in its context.
The suggested approach is based on the internationally accepted principles of the scientific style, the specific features of its being: the universal character, exactness, briefness, logic, accuracy, etc. According to A. Remache, "scientific English is more restricted than the General English," and "the main concern of science is to classify clearly what is consistently true and what may be reasonably predicted." This provides for exact and clear presentation of the material, easily understandable to the target readership, i.e. the group of people who regularly read a particular scientific journal. For example, in order to meet the requirements of a journal, the author of a paper should fully acquire the universal lexical and grammatical structure of the scientific language and master some specific lexical units and morphological forms.

The suggested Scientific English course has been developed with the account of integration of the following teaching principles: maximizing the use of the target language, providing error correction feedback, teaching grammar within contexts, presenting meaningful information related to a student's specific area, the extensive integration of authentic materials. In addition, the course is based on the student-centered approach, which provides for constant development of students' creativity and contributes to their effective work in science.

However, in teaching foreign languages to non-linguistics students, we currently face a number of learner's problems associated with their inability to present a scientific idea in a clear and unambiguous way, inability to convey information using brief and embracing phrases, use of multiple inappropriate phrases, wordcombinations and robust language patterns, inconsistency in narration, and etc. described in more detail in works $[8 ; 25-26]$. It is to be noted that non-linguistics students engaged in research work acquired all the necessary skills at the bachelor level so that they are capable of structuring their scientific text in the native language according to a certain logic of description, making a well-structured plan of their written speech, etc. 
As there exist unified requirements to the structure of the English scientific text (both written and oral), we choose to stick to them while developing the program for the Scientific English course. That should considerably facilitate professional contacts of our scientists with their foreign colleagues within the rapidly changing international community.

Therefore, an important idea of our approach is to avoid translation as a means of "delivering" native language texts to foreign language audience, and to encourage master students to write reports, abstracts, summaries in the target language, using the grammatical and lexical structures learnt in the Scientific English course.

The many concepts that are known to be peculiar to science and technology need specialized words and expressions. Observation, measurement, formulation of hypotheses, experimentation, classification and prediction are typical to any scientific enquiry. The different sciences carry out these activities each using its own bulk of word categories such as technical abbreviations, symbols and formulae, highly technical (diode, semi-conductor etc.) and subtechnical vocabulary (method, function, take place, occur etc.). Thus, to ensure a successful performance of these acts, the foreign language learner is expected to have a specialized English vocabulary as well as general vocabulary peculiar to explaining scientific procedures (integrate, isolate, differentiate etc.) at his disposal [20].

Data obtained in a series of specially conducted language pedagogy experiments show that the course in question helps to discipline the intellectual activity of students and significantly facilitates the process of producing a self-generated text in a foreign language. In addition, we suggest that the currently established English terminology be widely used as an integral part of the courses in core subjects, which appears especially important due to the constant introduction of new notions and terms and the necessity of their immediate and adequate interpretation in a foreign language.

\section{Adapting the University Curriculum and the Teaching Strategy}

The effectiveness of the suggested teaching strategy is based on the combination of four basic components, namely online lectures on scientific writing, practical classes, students' individual work, and face-to-face individualized consultations with the teacher of English. Besides, the skill-based and step-by-step instruction can help master students master basic skills and become confident and successful in their ability to perform the suggested course taught in a foreign language. All the components form a coherent whole that functions as an integral part of the educational process and may only be considered separately, which we do in the following section, for research purposes.

Teaching Conditions. As mentioned above, the course is designed to introduce students to the necessary vocabulary and grammar specific for professional communication, and language skills related to different writing activities. It has the right balance of hours of study to maximize efficiency in a short period of time (72 hours), with 16 hours of online lectures on theoretical issues of the scientific writing activity, 48 hours of practical classes and the rest of the time dealing with face-to-face learning.

Firstly, a series of online lectures based on the textbook "How to Write and Publish a Scientific Paper" by R. Day is designed to encompass a variety of issues, namely: "The Introduction into modern scientific writing"; "Organization of a scientific paper"; "Writing an abstract for a scientific paper. Types of abstracts"; "Writing an introduction for a scientific paper"; "Writing an Effective Materials and Methods Section in the Research Manuscript"; "Writing the Results Section"; "Writing the Discussion section. Components of the Discussion"; "Citing the references: basic rules, examples of different reference styles".

The theoretical part is followed by practical classes (seminars). Within 48 hours, a group of master students is supposed to do the course activities: along with studying and practicing the characteristic elements of scientific speech, 
students are taught to analyze authentic papers and classify their subject-oriented lexical and grammar structures. Teaching is based on the problem-solving technique, the latter being set by the science supervisor who is expected to recommend useful resources, including online ones, and to explore the subject of research with the students.

All the time, the group study the recommended literature and discuss it with the teacher of English. Together they analyze the structure of the papers, highlight the terminology, useful words and word-combinations, collocations, grammar; with students learning to use them in writing (e.g. note-taking, in-class free writes, passage commentaries, self-editing, short summaries of assigned readings, synthesis or critique, restating discipline-specific vocabulary to clarify technical language, giving definitions for technical terms).They also practice their skills through describing in English the procedure, strategy, the setting and the results of the experiments.

Finally, the group is to write a conference report related to their real scientific work, with the science supervisors helping the students make a plan and outline the report. The students give a presentation of their work to the class, submit it to the open-access "The Student online journal» for criticism or support from their group-mates, science supervisors and faculties. Meanwhile, students compare papers, distinguish and analyze the language used for expressing the same ideas in a foreign language. In the process, the students attend and speak at a wide range of conferences organized by staff across the course, thus acquiring the communicative skills needed for their professional activity, gaining new knowledge about the areas in which contemporary scientists are involved.

Thus, the collaborative work of the English Department teacher, science supervisors and interested teaching staff, faculty provide for the integrative education of master students.

The final assessment of students' progress is carried out both in traditional forms, such as pass/fail tests and exams, and through their participation in the Reports Contest, which al- lows us to make a comprehensive analysis of the acquired skills and evaluate the effectiveness of the strategy.

Evaluation Criteria. A special bank of test assignments has been developed to provide the course with the teaching materials designed for providing a scientific and methodological base for monitoring and evaluating master students' progress. Monitoring aims at planned and permanent check of master students' skills in writing. It is designed for collecting data on the progress and success in acquiring the teaching material and stimulating the activity of students. While evaluating the effectiveness of the suggested strategy, special emphasis is placed on checking students' ability to write a conference report.

At the stage of its writing, unified text evaluation criteria were applied, namely:

- relevance to the subject;

- completeness and consistency of disclosure topics;

- ability to summarize and draw conclusions;

- ability to work with sources of information;

- text coherence (semantic, syntax, lexical and grammar correlations);

- communicative continuity (topic sentence at the beginning of a paragraph, logical connection with the next paragraph through final sentence, use of connecting words, repetition of lexical elements at the beginning and end of adjacent sentences, etc.);

- compliance of the abstract design with the requirements of the English Department;

- the number of misused connective elements;

- the number of mistakes made in spelling, grammar and punctuation;

- use of the terminology accepted in a specific area of study;

- selection of literature.

\section{Conclusion}

The integrative teaching strategy described in the paper is yet at the stage of its further de- 
velopment, more detailed critical analysis and focused data collection. It also needs designing additional teaching materials and involving multiple resources, including a better structured syllabus, assignments, discussion groups, projects, class notes, video material and the power points for the lectures, students' workbooks, testbooks as well as links to websites that can provide additional representations of a subject under discussion.

So far, the research has led to a conclusion that the integration of traditional in-class activities, online lectures, and the collaborative efforts of two departments (major and foreign language) in the educational process is really efficient. It also has good potential for online education essential for students located quite a distance away.

In this context, it is essential to note that, according to Russian researchers E. Tareva and N. Gal'skova [27], modern information and communication technologies, project learning, programmed instruction, distance learning have already paved the way to modern linguistics and are significantly developing as effective tools in teaching foreign languages.

Despite this fact, the authors of this article believe that compared to the traditional approach, the suggested integrative teaching strategy is more carefully classified, is within the general trend of shifting to advanced technologies, and guarantees a high educational output.

\section{References}

1. Bailey, S. (2014). Academic Writing: A Handbook for International Students. Routledge, $260 \mathrm{p}$.

2. Basturkmen, H. (2010). Developing Courses in English for Specific Purposes. UK: Palgrave Macmillan, $157 \mathrm{p}$.

3. Day, R. (1998). How to Write and Publish a Scientific Paper. ORIX Press, 275 p.

4. Malmfors, B., Garnsworthy, P., Grossman, M. (2009). Writing and Presenting Scientific Papers. Nottingham University Press, $153 \mathrm{p}$.

5. Alenkina, T.B. (2015). Academic Writing in the Sciences: Theory and Practice. Moscow: MIPT Publ., 274 p.
6. Alenkina, T.B. (2018). Academic Writing and Its Development in Russia: Genre Approach. Vysshee obrazovanie $v$ Rossii $=$ Higher Education in Russia. Vol. 27, no. 5, pp. 110-113. (In Russ., abstract in Eng.)

7. Bazanova, E.M., Korotkina, I.B. (2017). Russian Writing Centers Consortium. Vysshee obrazovanie $v$ Rossii $=$ Higher Education in Russia. No. 4, pp. 50-57. (In Russ., abstract in Eng.)

8. Dobrynina, O.L. (2018). Problems of Academic Writing: Lexical Errors, their Causes and Correction Strategies. Vysshee obrazovanie v Rossii $=$ Higher Education in Russia. Vol. 27, no. 10, pp.75-83. DOI: https://doi.org/10.31992/08693617-2018-27-10-75-83. (In Russ., abstract in Eng.)

9. Korotkina, I.B. (2018). Academic Writing in Russia: The Urge for Interdisciplinary Studies. Vysshee obrazovanie $v$ Rossii = Higher Education in Russia. Vol. 27, no. 10, pp. 64-74.DOI: https:// doi. org/10.31992/0869-3617-2018-27-10-64-74 (In Russ., abstract in Eng.)

10. Mileyeva, M.M. (2018). International and National in Academic Paper. Vysshee obrazovanie $v$ Rossii $=$ Higher Education in Russia. Vol. 27, no. 5, pp. 114-120. (In Russ., abstract in Eng.)

11. Yarotskaya, L.V. (2016). Inostrannyi yazyk $i$ stanovlenie professional'noi lichnosti (neyazykovoi vuz) [Foreign Language and Developing a Professional Identity (Non-linguistics University):]. Moscow: TRIUMF Publ., 258 p. (In Russ., abstract in Eng.)

12. Sheypak, S.A. (2020). Academic Writing: Critics of the Traditional EAP Approach. Vysshee obrazovanie $v$ Rossii $=$ Higher Education in Russia. Vol. 29, no. 2, pp. 92-103. DOI: https://doi. org/10.31992/0869-3617-2020-29-2-92-103 (In Russ., abstract in Eng.)

13. Spack, R. (1988). Initiating ESL Students into the Academic Discourse Community: How Far Should We Go? TESOL Quarterly, no. 22, pp. 29-51.

14. Raimes, A. (1983). Techniques in Teaching Writing. Hong Kong: Oxford American English, 165 p.

15. Hyland, K. (2003). Second Language Writers. In: Second Language Writing (Cambridge Language Education, pp. 31-53). Cambridge: Cambridge University Press. DOI: https://doi. org/10.1017/CBO9780511667251.005

16. Yarotskaya, L.V. (2016). Mobile Teaching-andLearning Technologies as a Means of Modelling Professional Domain Contexts. Vestnik of 
MGLU=Bulletin of Moscow State Linguistic University. Vol. 16 (755), pp. 112-124. (In Russ., abstract in Eng.)

17. Bowker, L. (1998). Using Specialized Monolingual Native-Language Corpora as a Translation Resource: A Pilot Study. Meta: Journal des Traducteurs / Meta: Translators 'Journal. Vol. 43, no. 6, pp. 631-651.

18. Cohen, A. (2005). Strategies for Learning and Performing L2 Speech Acts. Intercultural Pragmatics. Vol. 2(3), pp. 275-301.

19. Harmer, J. (2001). The Practice of English Language Teaching. Longman, $372 \mathrm{p}$.

20. Remache, A. (2013). The Universality of Scientific Discourse. International Journal of English Language Teaching. Vol. 1, issue 2, pp. 37-52.

21. Vygotsky, L.S. (1997). The Historical Meaning of the Crisis of Psychology. In: The Collected Works of L.S. Vygotsky. Vol. 3. New York: Plenum, pp. 233-344.

22. Kraevskiy, V.V., Hutorskoy, A.V. (2007). Osnovy obucheniya. Didaktika i metodika: ucheb. posobie dlya stud. vyssh. ucheb. zavedenii [Fundamentals of Teaching: Didactics and Methods. Textbook.]. Moscow: Akademia Publ., 352 p. (In Russ.)

23. Klochkova, O.F., Komochkina, E.A. (2016). Insight into the Structure. Textbook for Physics
Master Students. Moscow: NRNU MEPhI Publ., $76 \mathrm{p}$.

24. Cavage, C. (2017). University Success Oral Communication, Transition Level with MyEnglishLab. Pearson Education, 198 p.

25. Dobrynina, O.L. (2017). Grammar Errors in Academic Writing in English: Causes and Strategies of Correction. Vysshee obrazovanie $v$ Rossii $=$ Higher Education in Russia. No. 8-9, pp. 100-107. (In Russ., abstract in Eng.)

26. Klochkova, O., Komochkina, E., Mustafina, A. (2016). "Triad" Strategy as an Effective Way of Developing Professional Communication Skills of Physics and Mathematics Students. Procedia-Social and Behavioral Sciences. Vol. 236, pp. 271-276. DOI: https://doi.org/ 10.1016/j.sbspro.2016.12.028

27. Tareva, E.G, Gal'skova, N.D. (2013). [Innovations in Teaching Language and Culture: Pro et Contra]. Inostrannye yazyki v shkole = Foreign Languages for Schools. Vol. 10, pp. 2-8. (In Russ., abstract in Eng.)

The paper was submitted 14.04.19 Received after reworking 24.03.20 Accepted for publication 10.04.20

\section{Интегративная стратегия обучения как эффективный способ развития навыков письма у студентов нелингвистического вуза}

Комочкина Елена Анатольевна - канд. пед. наук, ст. преподаватель. Е-mail: Komochkina2010@yandex.ru

Национальный исследовательский ядерный университет «МИФИ», Москва, Россия Адрес: 115409, г. Москва, Каширское шоссе, 31

Московский государственный областной университет, Москва, Россия Адрес: 141014, Московская область, Мытищи, ул. Веры Волошиной, 24

Яроцкая Аюдмила Владимировна - А-р пед. наук, проф. E-mail: lvyar@yandex.ru Московский государственный лингвистический университет, Москва, Россия Адрес: 119034, г. Москва, Остоженка, 38, стр. 1

Аннотация. В статье рассматриваются некоторье междисииплинарные, контекстуальные и лингвистические аспекть развития языковых навьков, необходимых для написания научных работ на иностранном язьке. Предлагаемая в работе стратегия обеспечивает теоретическую основу для разработки интегрированного курса обучения, включаюшего три основных компонента образовательного прочесса: обучение навыкам письма на иностранном язьке, использование онлайн-платформь обучения и учёт универсальности стиля научного языка, которыми характеризуется профессиональное общение учёных всего мира. $B$ статье вьявляются пробель в обучении навыкам письма на иностранном язьке, названь 
типичнье ошибки и предлагается способ их преодоления путём внедрения в учебньий проиесс интегративной стратегии. В работе также рассматриваются некоторье способы реализачии стратегии В отношении интеграчии традичионного и онлайн-обучения с помошью введения элементов профессионального дискурса, типичного для научной профессиональной коммуникачии, выявления формульньх вьражений и грамматических образиов с целью их использования в профессиональном дискурсе, т.е. образцов, с опорой на которые конструируется связный текст. Использование предлагаемой стратегии приводит к развитию способностей обучающихся писать профессионально значимые научные работь на иностранном языке.

Ключевые слова: курс научного английского языка, иностранный язык, нелингъистические университеть, профессиональный дискурс, интегративная стратегия обучения, навьки академического письма

Аля иитированил: Komochkina, E.A., Yarotskaya, L.V. Integrative Teaching Strategy for Developing Writing Skills in Non-Linguistics Master Students // Высшее образование в России. 2020. T. 29. №. 5. C. 64-72.

DOI: https://doi.org/10.31992/0869-3617-2020-29-5-64-72

Статья поступила в редакиию 14.04.19

С доработки 24.03.20

Принята к публикачии 10.04.20

\begin{tabular}{|lc|}
\hline НАУЧНАЯ ЭАЕКТОННАЯ & \\
\hline ВОПРОСЫ ФИАОСОФИИ & 10,602 \\
\hline ВОПРОСЫ ОБРАЗОВАНИЯ & 9,420 \\
\hline СОЦИОАОГИЧЕСКИЕ ИССАЕАОВАНИЯ & 7,608 \\
\hline ПСИХОАОГИЧЕСКАЯ НАУКА И ОБРАЗОВАНИЕ & 4,363 \\
\hline ФИАОСОФСКИЕ НАУКИ & 3,246 \\
\hline ОБРАЗОВАНИЕ И НАУКА & 2,649 \\
\hline ЭПИСТЕМОАОГИЯ И ФИАОСОФИЯ НАУКИ & 2,229 \\
\hline ИНТЕГРАЦИЯ ОБРАЗОВАНИЯ & 2,024 \\
\hline ПЕААГОГИКА & 1,420 \\
\hline ВЫСШЕЕ ОБРАЗОВАНИЕ в РОССИИ & 1,252 \\
\hline УНИВЕРСИТЕТСКОЕ УПРАВАЕНИЕ: ПРАКТИКА И АНААИЗ & 1,043 \\
\hline ВЫСШЕЕ ОБРАЗОВАНИЕ СЕГОАНЯ & 0,980 \\
\hline АЦМА МАТЕ & 0,544 \\
\hline ИНЖЕНЕРНОЕ ОБРАЗОВАНИЕ & 0,343 \\
\hline
\end{tabular}

